\title{
Comparison of environmental characteristics at Cicuta virosa habitats, an endangered species in South Korea
}

\author{
Cha Jeong Shin, Jong Min Nam, Jae Geun Kim* \\ Department of Biology Education, Seoul National University, Seoul 151-748, Korea
}

\begin{abstract}
Cicuta virosa is an endangered species in Korea, which is a southern marginal area. To conserve and restore habitats of this plant, we investigated water and soil environmental characteristics and vegetation at four habitats during the growing season. The $C$. virosa habitats differed in community structure, water and substrate properties, and water regime. Although the total distribution ranges of the water and soil environments for C. virosa were wide and overlapped with the optimal environmental range of distribution of accompanying species, the optimal water level range for $C$. virosa was defined as $7 \pm 3.5 \mathrm{~cm}$. Water level was adjusted by substrate structure such as a mound of $P$. japonica and a floating mat comprised of accompanying species. A floating mat was an aid to maintain an optimal and stable water level in deep or fluctuating water and to prevent strong competition with prolific macrophytes. The GS sampling site, which had floating mats, could be a good model for C. virosa conservation in a warm temperate region, whereas the PC sampling sites, which experienced a water shortage in spring, provided a clue about the decline in C. virosa population size.
\end{abstract}

Keywords: conservation, floating mat, plant distribution, water depth, water-hemlock

\section{INTRODUCTION}

Cicuta virosa $\mathrm{L}$. (water hemlock) is a perennial herb native to northern and central Europe, northern Asia, and northwestern North America (Mulligan and Munro 1980, Lee 2003). Its population size has decreased in Korea which is a southern marginal area of distribution. $C$. virosa has been designated an endangered species by the Natural Environment Conservation Law and as a rare plant by the national arboretum in Korea (Korean Environment Institute 2005, National Arboretum 2009). C. virosa is also listed in 17 of 47 Japanese prefectural red lists (Japanese Wildlife Research Association 2012). In Hungary where almost all fens had been destroyed, C.virosa was a protected species (Tatár 2010). Few studies have investigated the specific properties of endangered plants to plan counter-measures for conservation in Korea (Suh et al. 2001). A few surveys of wild and rare plants in Korea have been carried out in the last decade due to urgency (e.g., Yoo et al. 2004, Jang et al. 2009, Song et al. 2010) and a series of studies on the conservation strategy for endangered and reserved plants based on the ecological and genetic characteristics has been performed by the National Institute of Environmental Research. However, C. virosa has not been a target species.

The water hemlock produces a lateral tuber before the root system dies in the fall and initiates a new plant the following spring (Kingsbury 1964). The plants persist by producing several new rootstocks from buds around the perimeter of the old rootstock (Mulligan and Munro 1980). The roots and tubers of C. virosa are toxic (Panter et al. 1988), and most studies on C. virosa have concen-

\section{Open Access http://dx.doi.org/10.5141/ecoenv.2013.003}

This is an Open Access article distributed under the terms of the Creative Commons Attribution Non-Commercial License (http://creativecommons org/licenses/by-nc/3.0/) which permits unrestricted non-commercial use distribution, and reproduction in any medium, provided the original work is properly cited.
Received 28 December 2012, Accepted 21 January 2013

*Corresponding Author

E-mail: jaegkim@snu.ac.kr

Tel: +82-2-880-7896 
trated on its toxicology and pharmacology (e.g., Sarreveld 1975, Panter et al. 1988, Strauß et al. 1996). Water hemlock grows in a very wet substrate and is usually found growing in streams, ditches, lakes, rivers, or marshy areas. This high water requirement limits its range (Panter et al. 1988). Other environmental characteristics have not been studied well, even though basic ecological information is necessary to conserve $C$. virosa.

The primary goal of this study was to understand the environmental characteristics of $C$. virosa habitats. The specific objectives were to identify the major factors determining C. virosa distribution and the reason that the C. virosa population has decreased by comparing the water and soil environmental characteristics of C. viro$s a$ habitats. The water regime is a major determinant of plant community development and patterns in wetlands (Spence 1967, Casanova et al. 2000, Heegaard et al. 2001) and soil variable gradients are also important in determining plant community composition (Fitter 1982, Keddy 1984, Nilsson et al. 1989). An optimal environmental range of distribution for specific species has been proposed for several hydrophytes (Kwon et al. 2006, Lee et al. 2007, Yoon et al. 2011). Our study could be a method to understand the reason of decrease in population size of C. virosa and to seek a management strategy for conservation and restoration of the C. virosa habitat, an endangered plant.

\section{MATERIAL AND METHOD}

\section{Study Site Description}

Only four habitats of C. virosa are known in South Korea, and we studied these four habitats (Table 1). The Hoengseong habitat (HS1 and HS2) was located between a grazing land and low hills at $520 \mathrm{~m}$ a.s.l. The distance between HS 1 and HS2 was about $700 \mathrm{~m}$. HS1 was a 12 year

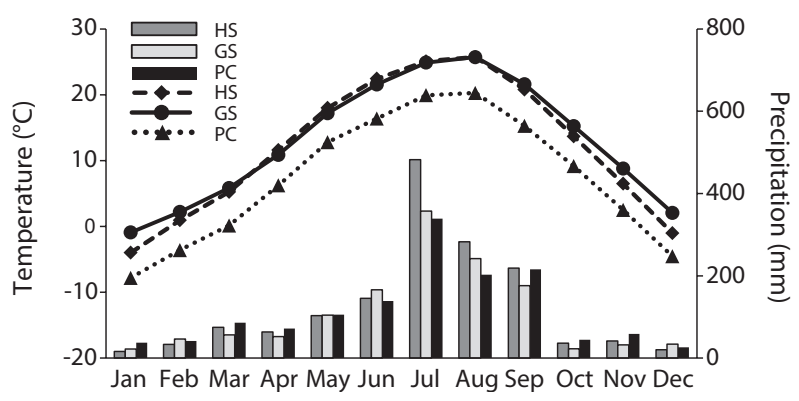

Fig. 1 Monthly mean temperature and precipitation at Hoengseong (HS), Gunsan (GS), and Daegwanryeong (PC) during 2007- 2011 (data from National Weather Service 2011)

old abandoned paddy field. HS2 was a narrow streamlet, and water depth and vegetation were different between them. The Gunsan habitat (GS) is an abandoned reservoir that supplied water to a rice paddy at $28 \mathrm{~m}$ a.s.l. and is $2^{\circ}$ south of HS. Water flows into the reservoir from farming land through an agricultural irrigation system in May and June and flows out during the rainy season in July. The Pyeongchang habitat (PC) was the highest at $793 \mathrm{~m}$ a.s.l. and the most northern among the four sites. This site has been protected by fences since 2008 . The waterway has been altered by road construction and this resulted in drying at this site in the spring. We verified that there has been a marked decrease in the $C$. virosa population since an earlier informal survey was performed in 2008. The Gangneung habitat (DG) was recorded for the first time as a C. virosa habitat in South Korea. Although it is a private agricultural waterway, it has been fenced and protected since 2007 with agreement by the owner. Water at this site became dependent on an artificial supply in 2011, and the C. virosa population size decreased to $<10$ individuals.

PC was the coldest with a heavy snowfall in winter (Fig. 1). HS and GS showed similar temperatures during the summer. However, HS was colder than GS during the winter. GS maintained above freezing temperatures except in January and HS received abundant rain in summer.

Table 1. Study sites (Cicuta virosa habitats)

\begin{tabular}{|c|c|c|c|c|c|}
\hline Habitat name & Code & GPS information & $\begin{array}{c}\text { Altitude } \\
\text { (a.s.l.) }\end{array}$ & $\begin{array}{l}\text { Population } \\
\text { size in } 2011\end{array}$ & Type \\
\hline Hoengseong & $\begin{array}{l}\text { HS1 } \\
\text { HS2 }\end{array}$ & $\mathrm{E} 128^{\circ} 10^{\prime} 05^{\prime \prime} \mathrm{N} 37^{\circ} 29^{\prime} 28^{\prime \prime}$ & $520 \mathrm{~m}$ & $\begin{array}{r}170 \\
70\end{array}$ & $\begin{array}{l}\text { HS1: Abandoned paddy field } \\
\text { HS2: Stream let }\end{array}$ \\
\hline Gunsan & GS & $\mathrm{E} 126^{\circ} 43^{\prime} 12^{\prime \prime} \mathrm{N} 35^{\circ} 55^{\prime} 58^{\prime \prime}$ & $28 \mathrm{~m}$ & $>500$ & $\begin{array}{l}\text { Reservoir } \\
\text { (abandoned since 2000) }\end{array}$ \\
\hline Daegwan-ryeong & PC & $\mathrm{E} 128^{\circ} 40^{\prime} 26^{\prime \prime} \mathrm{N} 37^{\circ} 41^{\prime} 10^{\prime \prime}$ & $793 \mathrm{~m}$ & $<40$ & $\begin{array}{l}\text { Wet meadow } \\
\text { (fenced since 2008) }\end{array}$ \\
\hline Gangneung & DG & $\mathrm{E} 128^{\circ} 44^{\prime} 59^{\prime \prime} \mathrm{N} 37^{\circ} 34^{\prime} 20^{\prime \prime}$ & $592 \mathrm{~m}$ & $<10$ & $\begin{array}{l}\text { Agricultural waterway } \\
\text { (fenced since 2007) }\end{array}$ \\
\hline
\end{tabular}




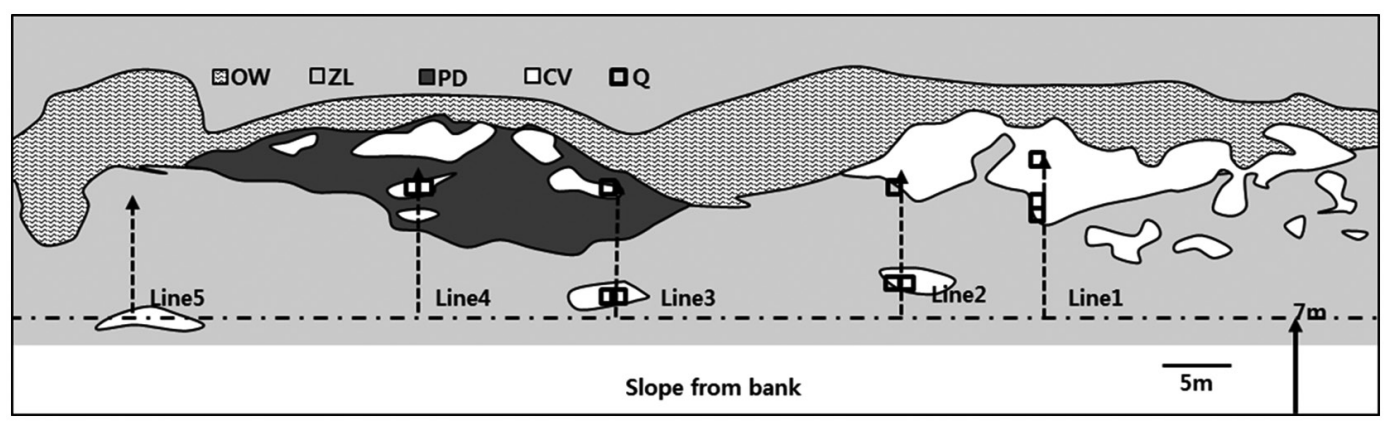

Fig. 2 Location of line transects and quadrats at GS, OW: open water, ZL: Zizania latifolia, CV: Cicuta virosa, PD: Paspalum distichum, Q: Quadrats

\section{Vegetation survey}

We established nine $1 \mathrm{~m} \times 1 \mathrm{~m}$ permanent quadrats at HS1, five at HS2, 11 at GS, and three at PC according to $C$. virosa population size and investigated the cover, density, and height monthly during growing season in 2011, based on a modification of the Braun-Blanquet plant sociological method (Mueller-Dombois and Ellenberg 2003, Kim et al. 2004). A water gradient from the bank to the floating mat was observed at GS, where sizable C. virosa monopopulations were distributed. To determine the topography and the $C$. virosa community structure covering $C$. virosa mono-populations, we established five fixed line transects at representative locations at GS, and investigated vegetation distribution at each transect using the line intercept method (Canfield 1941). The 11 quadrats at GS were placed on those transects (Fig. 2).

\section{Water environment analyses}

We measured water level at each quadrat and fixed places comprised of major accompanying species monopopulations of every study site with a $1 \mathrm{~m}$ stick ruler. Water level was defined as the distance from substrate surface that $C$. virosa rooted in such as a floating mat or mound of plant roots. It was positive when the surface was below the water table and negative when the surface was above the water table. Water temperature and dissolved oxygen (DO) were measured with a DO meter (model PDO-520; UKAS, Taipei, Taiwan). Conductivity (EC) was measured with a Corning Checkmate II (model 311; Corning, Lowell, MA, USA), and $\mathrm{pH}$ was measured with a $\mathrm{pH}$ meter (model AP 63; Fisher, Pittsburgh, PA, USA) in the field. We collected water samples at each quadrat and fixed places comprised of major accompanying species mono-populations in $125 \mathrm{ml}$ HDPE bottles once every month and brought them in a cool box to the laboratory and filtered them with a $0.45 \mu \mathrm{m}$ membrane filter. We also took free water samples around the mat near permanent quadrats and interstitial mat water by squeezing the mat around $C$. virosa roots at a depth of $0-15 \mathrm{~cm}$ in each quadrat at GS. Those samples were collected twice before and after inundation of the mat on April 30 and June 20, 2012. $\mathrm{NO}_{3}-\mathrm{N}$, $\mathrm{NH}_{4}-\mathrm{N}$, and $\mathrm{PO}_{4}-\mathrm{P}$ were analyzed by the hydrazine method (Kamphake et al. 1967), indo-phenol method (Murphy and Riley 1962), and ascorbic acid reduction method (Solorzano 1969), respectively. The content of cations such as $\mathrm{K}^{+}, \mathrm{Ca}^{2+}, \mathrm{Na}^{+}$, and $\mathrm{Mg}^{2+}$ was measured using an atomic absorption spectrometer (Model AA240FS; Varian, Palo Alto, CA, USA). We used SPSS 19.0 software (SPSS, Inc., Chicago, IL, USA), a one-way analysis of variance (ANOVA), and Duncan's post hoc test or a $t$-test at a $5 \%$ significance level for analyses.

\section{Substrate analyses}

Soil was collected once at a depth of $0-10 \mathrm{~cm}$ in a $20 \times$ $20 \mathrm{~cm}$ area at each quadrat and fixed locations of major accompanying species mono-populations at every study site with a soil hand auger, and gravel and organic debris were removed. Particularly at GS, the mat around the $C$. virosa roots at a depth of $0-15 \mathrm{~cm}$ was collected in April and June. The soil and mat were then sealed in plastic bags and transported to the laboratory. We passed the soil samples through a $2 \mathrm{~mm}$ sieve and determined soil texture using the hydrometer analysis method and a texture triangle (Sheldrick and Wang 1993). We measured $\mathrm{pH}$ and conductivity using a soil solution prepared by mixing wet soil and distilled water at a mass ratio of 1:5. The total volume of water in wet soil was measured as freshwater moisture immediately after passing it through a sieve, and the amount of soil particle moisture was measured as airdried moisture in air dried soil by oven drying at $105^{\circ} \mathrm{C}$ for $\geq 24$ hours. Oven dried mat samples were milled to pass 

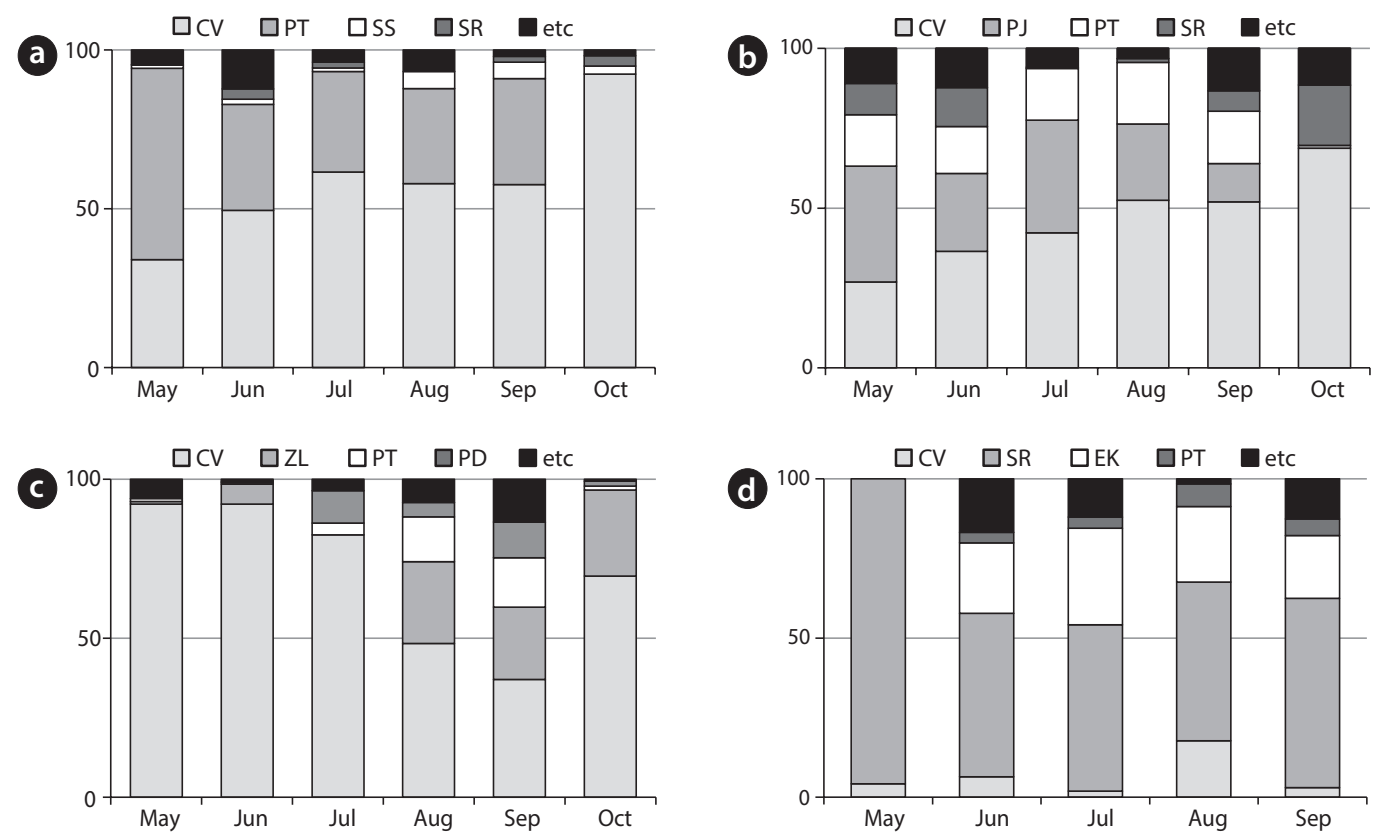

Fig. 3 Species composition and relative coverage of C. virosa community at HS1 (a), HS2 (b), GS (c) and PC (d), CV: Cicuta virosa, PT: Persicaria thunbergii, SR: Scirpus radicans, SS: Sium suave, PJ: Phragmites japonica, ZL: Zizania latifolia, PD: Paspalum distichum, EK: Eleocharis kuroguwai

through a $1 \mathrm{~mm}$ mesh screen (Sasser et al. 1991). Soil and mat organic matter contents were analyzed by the loss on ignition method (Boyle 2004). $\mathrm{NO}_{3}-\mathrm{N}$ and $\mathrm{NH}_{4}-\mathrm{N}$ were extracted with $2 \mathrm{M} \mathrm{KCl}$ solutions (Kim et al. 2004) and measured using the hydrazine (Kamphake et al. 1967) and indophenol methods (Murphy and Riley 1962), respectively. $\mathrm{PO}_{4}-\mathrm{P}$ was extracted with Bray No. 1 solution (Bray and Kurtz 1945) and measured using the ascorbic acid reduction method (Solorzano 1969). $\mathrm{K}^{+}, \mathrm{Ca}^{2+}, \mathrm{Na}^{+}$, and $\mathrm{Mg}^{2+}$ were extracted with $1 \mathrm{~N}$ ammonium acetate solution (Allen et al. 1974) and measured using an atomic absorption spectrometer. We used a one-way ANOVA and Duncan's post hoc test at the $5 \%$ significance level for analyses.

\section{RESULTS}

\section{Plant community structure}

Major accompanying species at HS1 (Fig. 3a), were $P$. thunbergii (coverage of 30-60\%) and Sium suave (coverage of 1-5\%). The coverage of $P$. thunbergii decreased with growth of $C$. virosa (coverage of 33-92\%). Major accompanying species at HS2 (Fig. 3b) were Phragmites japonica (coverage of $0-36 \%$ ) and $P$. thunbergii (coverage of 14$19 \%$ ). Relative coverage of C. virosa (coverage of 29-69\%) after the growing season increased due to wilt of companion species.
Major accompanying species at GS (Fig. 3c) were Zizania latifolia (coverage of $0-27.0 \%$ ) and $P$. thunbergii (coverage of $0.5-15.5 \%$ ). C. virosa (coverage of 37.1-92.2\%) dominated on the mat in May and June, and $Z$. latifolia fell down by heavy rain in July, whereas the C. virosa population located on the floating mat was relatively safe. In the case of PC (Fig. 3d), Scirpus radicans (coverage of 5196\%) dominated a broad area inside the fence, and a few C. virosa (coverage of 2-18\%) were distributed sparsely. C. virosa population size was very small at DG even though it has been protected and managed with an artificial water supply. S. radicans (coverage of $>90 \%$ ), dropwort, and several $C$. virosa were found at the DG site in June.

\section{Height and coverage of $C$. virosa}

C. virosa flowered in June at GS, in July at PC and in August at HS1, 2. During the blooming season, average height was $125 \pm 9.6 \mathrm{~cm}$ at GS, $126 \pm 22 \mathrm{~cm}$ at HS1, $128 \pm$ $21.8 \mathrm{~cm}$ at HS2 and $70 \pm 7.1 \mathrm{~cm}$ at PC (Fig. 4a). HS2, where tall P. japonica co-occurred, showed the greatest height. Particularly at GS, flowering adults fell down in June and juveniles grew up to an average height of $90 \mathrm{~cm}$ and showed a second growth peak in August. Blooming and withering at PC, where temperature was low and altitude was high, occurred 1 month earlier than those at HS. A few flower stalks were broken in July at PC; thus, we could not exactly measure height and coverage. 

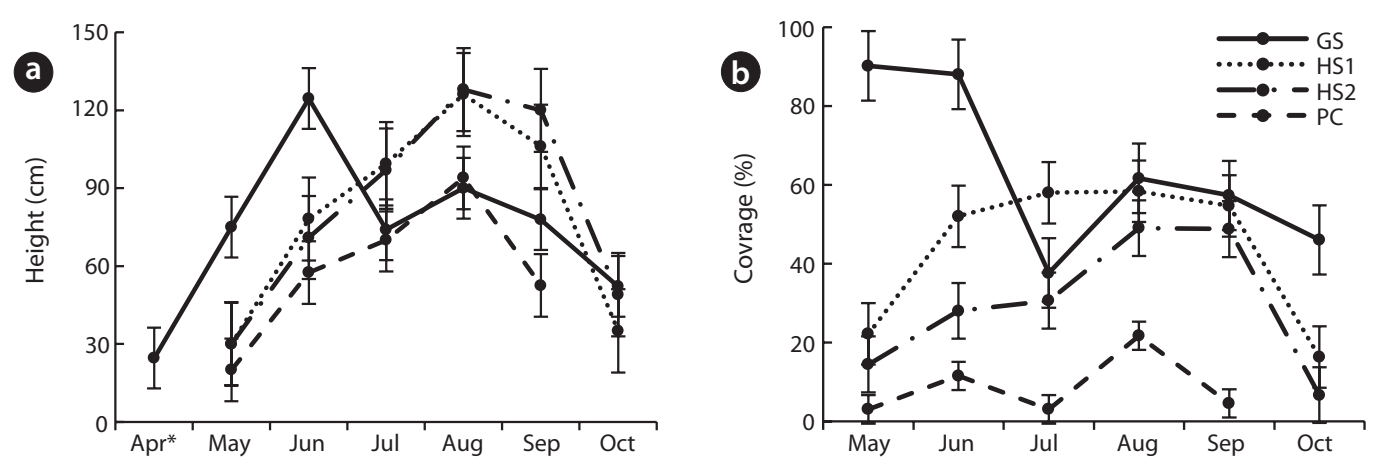

Fig. 4 Monthly change of height (a) and coverage (b) of C. virosa (Apr*: pilot survey result) Vertical bars indicate \pm SE
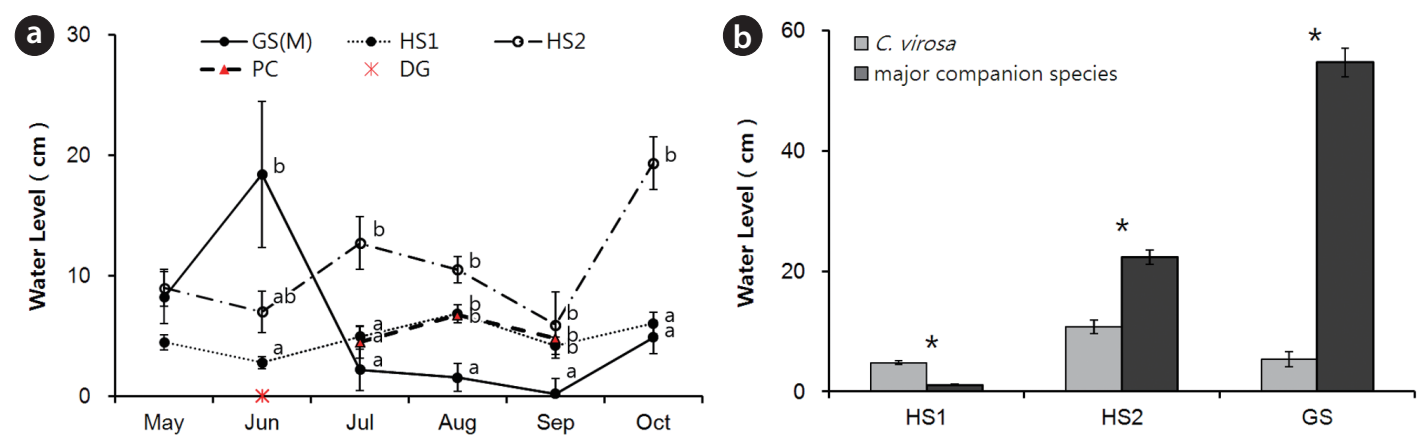

Fig. 5 Seasonal change in water level at HS1, 2, GS and PC (a) (no data at PC in May and June due to low subsurface water level) and comparison of water level at $C$. virosa quadrats and mono-populations of major companion species at each site during growing season (b) (HS1: P. thunbergii $\mathrm{n}=55$, HS2: P. japonica $\mathrm{n}=83, \mathrm{GS}$ : $Z$. latifolia $\mathrm{n}=68$ ) Letters on the graphs mean significant difference at the $5 \%$ level based on Duncan's test. Meaningful $\mathrm{t}$-test results at the $5 \%$ level are marked with *. Vertical bars indicate \pm SE

Coverage increased with growth and decreased after flowering (Fig. 4b). GS, where the climate was mild, showed earlier shoot sprouting than that of other species, so coverage in spring was up to $90 \%$.

\section{Water environment characteristics}

Seasonal changes and a significant difference among habitats in water level from substrate C.virosa rooted in were observed except in May (Fig. 5a) because of a high volume inflow at GS in June and heavy rain at HS in summer. We could not measure water level or collect water samples at PC in May and June due to the low subsurface water level. The water level at the $C$. virosa population was significantly different from that at the major companion species mono-population sites (P. thunbergii at HS1, P.japonica at HS2, and Z. latifolia at GS) in each habitat (Fig. 5b).

The water in all habitats was neutral or slightly acidic and mean $\mathrm{pH}$ was very similar (Fig. 6a). The EC range at $\mathrm{HS} 1,2$ and GS was very wide from 23.4 to $250.0 \mu \mathrm{S} / \mathrm{cm}$ and higher in spring and fall (dry season) than that in summer (Fig. 6b). But the EC values at PC (279.0-764.0 $\mu \mathrm{S} / \mathrm{cm})$ were far higher than those at other sites. The dissolved oxygen concentration in water was highest at HS2 in lotic water with a mean value of $5.7 \mathrm{mg} / \mathrm{kg}$ (Fig. 6c). In contrast, water temperature was lowest at HS2, and its year-round range was narrow. The highest water temperature was recorded at GS with low DO values (Fig. 6d).

The $\mathrm{NO}_{3}-\mathrm{N}, \mathrm{NH}_{4}-\mathrm{N}$, and $\mathrm{PO}_{4}-\mathrm{P}$ contents were low at HS throughout the entire growing season (Fig. 6e-g). The seasonal pattern of change in $\mathrm{NO}_{3}-\mathrm{N}, \mathrm{NH}_{4}-\mathrm{N}$, and $\mathrm{PO}_{4}-\mathrm{P}$ contents at GS was different from that at the other sites. $\mathrm{K}^{+}$and $\mathrm{Na}^{+}$concentrations were highest at GS with wide seasonal variations (Fig. 6h, i). But, the concentration of divalent cations at $\mathrm{PC}$ was excessively high such as the EC values (Fig. 6j, k). $\mathrm{NO}_{3}-\mathrm{N}, \mathrm{NH}_{4}-\mathrm{N}$, and $\mathrm{PO}_{4}-\mathrm{P}$ contents at DG were similar to the levels at GS, and cation concentrations and EC values at DG were similar to those at HS in June. Water environmental properties at the major companion species mono-populations were within the C. virosa population range at each site except water level. 

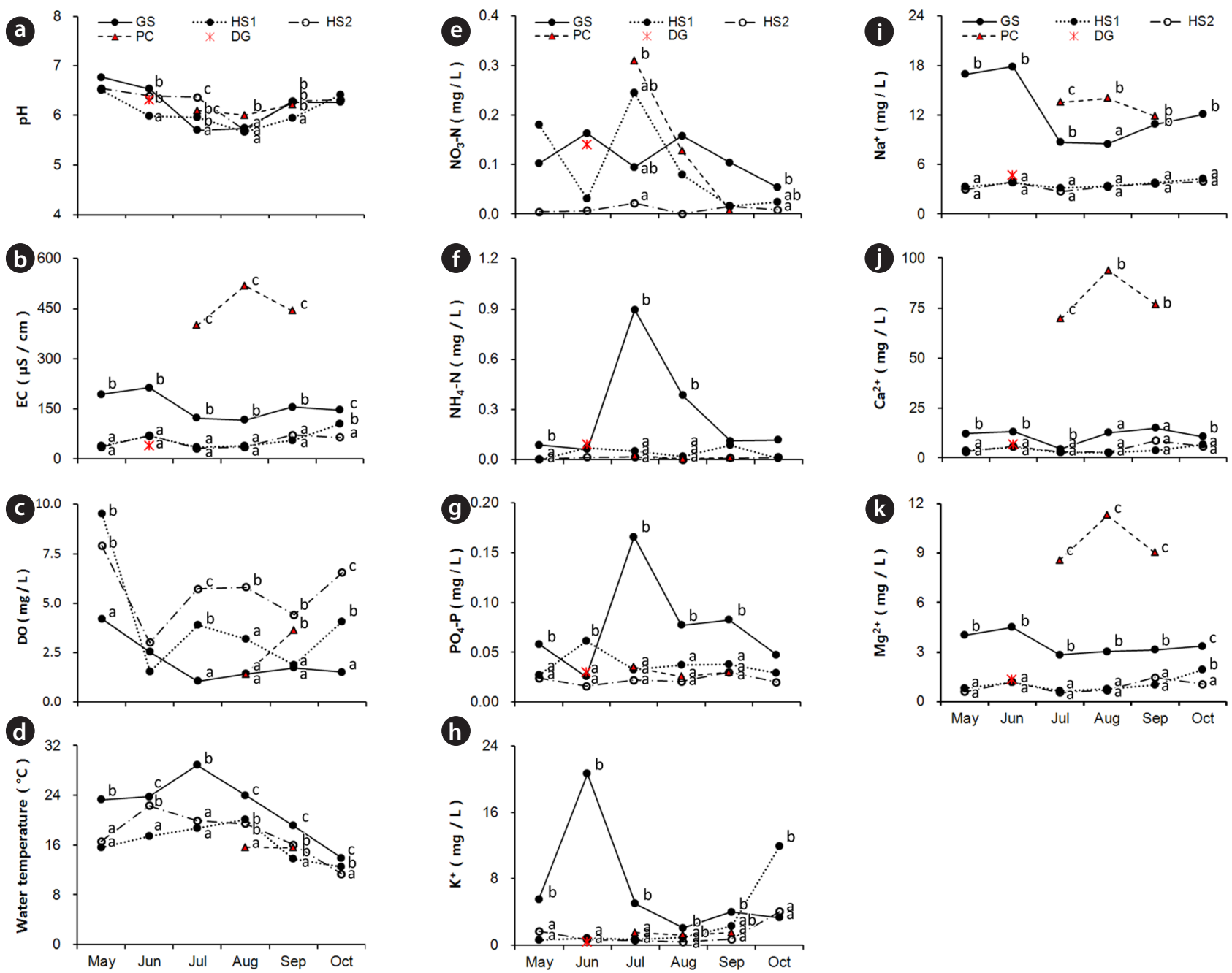

Fig. 6 Seasonal change in water environment characteristics at C. virosa habitats during the growing season in 2011. Letters on the graphs indicate significant difference at the $5 \%$ level based on Duncan's test. $H S 1: n=9, H S 2: n=5, G S: n=7, P C: n=3$ (no samples in May and June due to low subsurface water level)

Table 2. Means and ranges of soil environmental properties at C. virosa habitats in June

\begin{tabular}{|c|c|c|c|c|c|}
\hline & HS1 & HS2 & GS & PC & DG \\
\hline Soil factor & mean (range) & mean (range) & mean (range) & mean (range) & \\
\hline Fresh moisture (\%) & $44.5^{\mathrm{a}}(34.8 \sim 59.7)$ & $37.9^{\mathrm{a}}(35.7 \sim 40.1)$ & $66.7^{\mathrm{b}}(57.3 \sim 70.9)$ & $36.9^{\mathrm{a}}(30.3 \sim 44.4)$ & 41.6 \\
\hline Air-dried moisture (\%) & $11.2^{\mathrm{a}}(2.0 \sim 30.6)$ & $1.6^{\mathrm{a}}(1.2 \sim 2.0)$ & $11.8^{\mathrm{a}}(2.9 \sim 25.5)$ & $6.0^{\mathrm{a}}(2.1 \sim 10.5)$ & 8.0 \\
\hline LOI $(\%)$ & $7.3^{\mathrm{a}}(4.4 \sim 11.6)$ & $4.1^{\mathrm{a}}(3.6 \sim 4.5)$ & $14.3^{\mathrm{b}}(7.7 \sim 20.2)$ & $5.9^{\mathrm{a}}(3.4 \sim 8.5)$ & 5.8 \\
\hline $\mathrm{pH}$ & $4.9^{\mathrm{a}}(4.3 \sim 5.2)$ & $4.6^{\mathrm{a}}(4.6 \sim 4.7)$ & $4.4^{\mathrm{a}}(3.4 \sim 4.8)$ & $4.9^{\mathrm{a}}(4.4 \sim 5.7)$ & 5.8 \\
\hline $\mathrm{EC}(\mu \mathrm{S} / \mathrm{cm})$ & $34.0^{\mathrm{a}}(16.0 \sim 86.7)$ & $29.2^{\mathrm{a}}(25.1 \sim 33.2)$ & $246.7^{\mathrm{a}}(97.7 \sim 755.0)$ & $102.6^{\mathrm{a}}(87.7 \sim 123.9)$ & 13.3 \\
\hline $\mathrm{NO}_{3}-\mathrm{N}(\mathrm{mg} / \mathrm{kg})$ & $4.3^{\mathrm{ab}}(2.9 \sim 7.1)$ & $3.2^{\mathrm{a}}(2.4 \sim 3.9)$ & $6.5^{\mathrm{b}}(3.7 \sim 9.1)$ & $2.9^{\mathrm{a}}(0.7 \sim 6.1)$ & 2.8 \\
\hline $\mathrm{NH}_{4}-\mathrm{N}(\mathrm{mg} / \mathrm{kg})$ & $13.8^{\mathrm{ab}}(4.7 \sim 22.3)$ & $11.5^{\mathrm{a}}(5.0 \sim 18.0)$ & $32.5^{\mathrm{b}}(5.1 \sim 53.9)$ & $9.8^{\mathrm{a}}(1.8 \sim 23.4)$ & 12.3 \\
\hline $\mathrm{PO}_{4}-\mathrm{P}(\mathrm{mg} / \mathrm{kg})$ & $31.3^{\mathrm{a}}(13.5 \sim 48.1)$ & $12.5^{\mathrm{a}}(9.2 \sim 15.7)$ & $22.3^{\mathrm{a}}(4.7 \sim 40.3)$ & $13.8^{\mathrm{a}}(4.0 \sim 21.0)$ & 59.9 \\
\hline $\mathrm{K}^{+}(\mathrm{mg} / \mathrm{kg})$ & $104.0^{\mathrm{ab}}(61.6 \sim 185.2)$ & $45.1^{\mathrm{a}}(40.3 \sim 49.9)$ & $162.7^{\mathrm{b}}(101.4 \sim 224.5)$ & $70.1^{\mathrm{a}}(37.4 \sim 130.1)$ & 66.0 \\
\hline $\mathrm{Ca}^{2+}(\mathrm{mg} / \mathrm{kg})$ & $43.1^{\mathrm{ab}}(28.0 \sim 71.6)$ & $28.3^{\mathrm{a}}(22.2 \sim 34.5)$ & $102.4^{\mathrm{c}}(71.4 \sim 119.7)$ & $60.7^{\mathrm{b}}(52.9 \sim 74.7)$ & 46.2 \\
\hline $\mathrm{Na}^{+}(\mathrm{mg} / \mathrm{kg})$ & $837.5^{\mathrm{a}}(517.9 \sim 1358.9)$ & $517.2^{\mathrm{a}}(484.5 \sim 549.9)$ & $1219.8^{\mathrm{a}}(898.5 \sim 1553.5)$ & $12369.1^{\mathrm{b}}(609.7 \sim 18296.8)$ & 902.7 \\
\hline $\mathrm{Mg}^{2+}(\mathrm{mg} / \mathrm{kg})$ & $131.1^{\mathrm{ab}}(72.0 \sim 236.9)$ & $50.2^{\mathrm{a}}(46.1 \sim 54.3)$ & $286.3^{\mathrm{c}}(230.6 \sim 337.3)$ & $168.8^{\mathrm{b}}(51.8 \sim 235.1)$ & 111.2 \\
\hline Sand $(\%)$ & $39.4^{\mathrm{a}}(12.6 \sim 52.2)$ & $77.8^{\mathrm{b}}(75.1 \sim 80.4)$ & $50.7^{\mathrm{a}}(38.6 \sim 66.6)$ & $60.8^{\mathrm{ab}}(45.1 \sim 70.0)$ & 11.0 \\
\hline Silt (\%) & $51.7^{\mathrm{c}}(39.5 \sim 72.1)$ & $21.0^{\mathrm{a}}(17.7 \sim 24.2)$ & $43.0 \mathrm{~b}^{\mathrm{c}}(27.5 \sim 56.6)$ & $32.3^{\mathrm{ab}}(25.1 \sim 43.6)$ & 73.3 \\
\hline Clay (\%) & $8.9^{\mathrm{b}}(5.9 \sim 15.3)$ & $1.3^{\mathrm{a}}(0.6 \sim 1.9)$ & $6.3^{\mathrm{b}}(4.5 \sim 8.7)$ & $6.9^{\mathrm{b}}(4.5 \sim 11.2)$ & 15.6 \\
\hline
\end{tabular}

Letters on the table indicate significant difference at the $5 \%$ level based on Duncan's test. HS1 $n=9, H S 2 n=2, G S n=7, P C n=3, D G n=1$. 


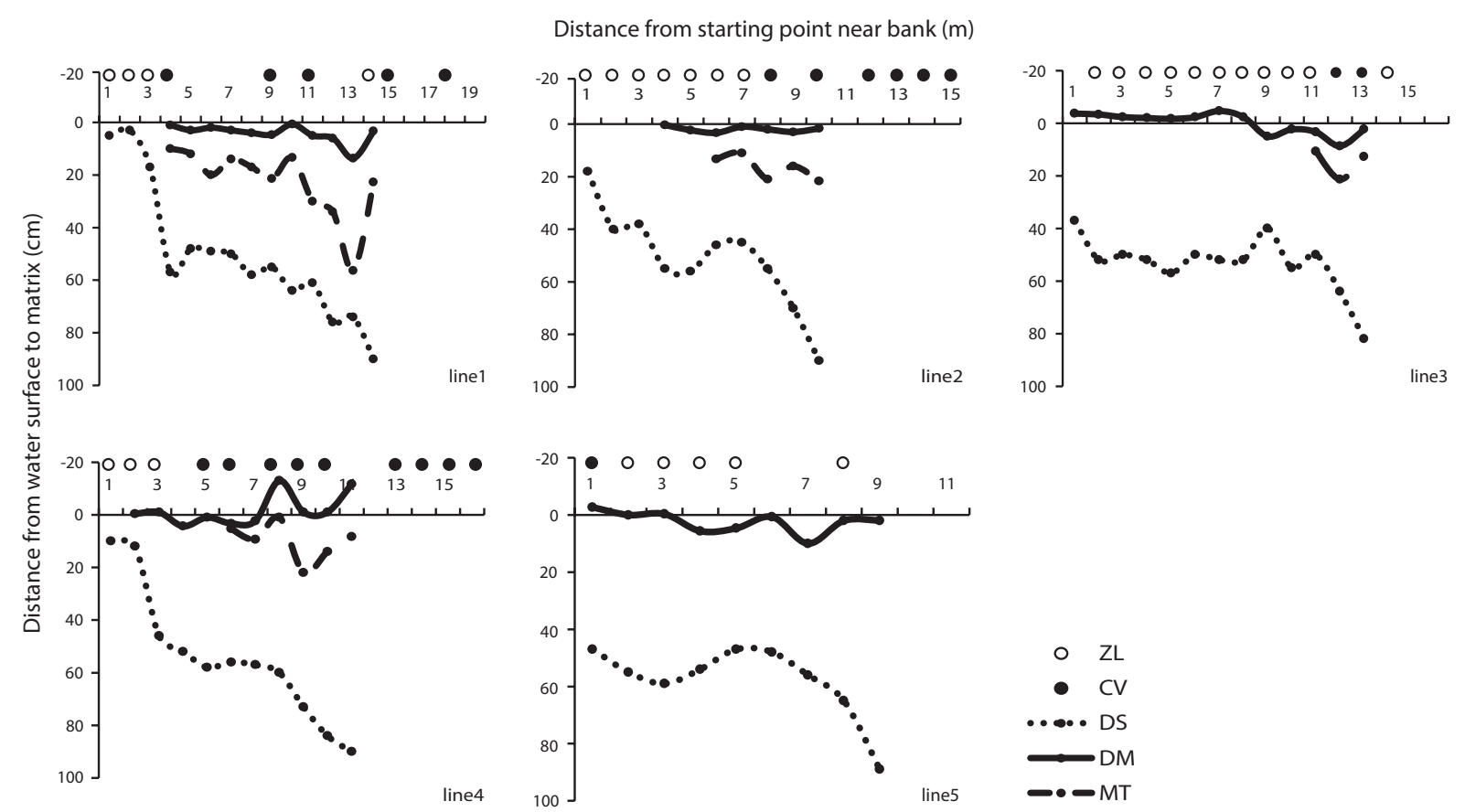

Fig. 7 Water depth and distribution of dominant plants profiles on five lines transects in GS reservoir in September. Horizontal axis is distance (meter) from start point near the bank. Vertical axis is distance $(\mathrm{cm})$ from water surface to soil and mat surface. For lines location, see Fig. 2. Dots indicate distribution of ZL and CV on the line. ZL: Z. latifolia, CV: C. virosa, SS: soil surface, MS: above border of mat, MT: mat thickness (below border of floating mat)

\section{Soil characteristics}

The common soil textures were silty loam and sandy loam. Soil was mostly sandy at HS2 and mostly silty at HS1 (Table 2). Average fresh moisture and air-dried moisture contents were $50.2 \pm 13.9 \%$ and $10.7 \pm 8.5 \%$, respectively. Fresh moisture content was significantly higher at GS than that at the other sites. The soil was acidic with a mean $\mathrm{pH}$ of 4.7. Organic matter content, EC, and $\mathrm{PO}_{4}^{-}$ $\mathrm{P}$ concentration were similar at the four sites. However, soil at DG was less acidic and had a lower EC value and higher $\mathrm{PO}_{4}$ - $\mathrm{P}$ concentrations than those at the other sites. Concentrations of $\mathrm{NO}_{3}-\mathrm{N}, \mathrm{NH}_{4}-\mathrm{N}, \mathrm{K}^{+}, \mathrm{Ca}^{2+}$ and $\mathrm{Mg}^{2+}$ at GS were significantly higher than those at the other sites, but the concentration of $\mathrm{Na}^{+}$at $\mathrm{PC}$ was ten times higher than that at GS. Soil properties at major companion species mono-populations were within the $C$. virosa population range at each site.

\section{A distinct habitat at Gunsan}

Because GS is a deep reservoir and C. virosa was growing on floating mats, we made additional water depth profiles at intervals of $1 \mathrm{~m}$ on line transects from a start point near the bank to $1 \mathrm{~m}$ of water depth (Fig. 7). C. virosa was mainly distributed on the floating mat and extended to an inaccessible region that was deeper than $1 \mathrm{~m}$, whereas $Z$. latifolia did not. There was loose and sunken mat on the fifth line; hence, water-hemlock was distributed only in the shallow water region near the bank.

Organic matter content of the mat, as a C. virosa substrate at GS, was $86.8 \pm 9.2 \%$ under a non-flooded condition on April 30 and $77.9 \pm 5.1 \%$ under inundation on June 20. Interstitial mat water had a significantly higher EC value and concentrations of $\mathrm{NO}_{3}-\mathrm{N}, \mathrm{NH}_{4}-\mathrm{N}, \mathrm{PO}_{4}-\mathrm{P}$, $\mathrm{K}^{+}, \mathrm{Na}^{+}, \mathrm{Ca}^{2+}$, and $\mathrm{Mg}^{2+}$ than free water around the mat. All values in June were higher than those in April except $\mathrm{NO}_{3}-\mathrm{N}$ content (Table 3). $\mathrm{NO}_{3}-\mathrm{N}$ content was highest in the interstitial mat water in April. $\mathrm{pH}$ values were slightly lower in interstitial mat water, but the difference was not significant.

\section{DISCUSSION}

\section{Chemical characteristics of Cicuta virosa habitat environment}

Based on the water chemistry of some typical natural wetlands (Kadlec and Knight 1996), water chemical properties in C. virosa habitats were general level except two factors. First, the range and seasonal change of $\mathrm{NH}_{4}-\mathrm{N}$ 
Table 3. Water properties of free water around mat and interstitial mat water at GS

\begin{tabular}{|c|c|c|c|c|}
\hline \multirow{2}{*}{ Factor } & \multicolumn{2}{|c|}{ Non-flooded } & \multicolumn{2}{|c|}{ Flooded } \\
\hline & Free $(n=6)$ & Interstitial $(n=6)$ & Free $(n=6)$ & Interstitial $(n=6)$ \\
\hline $\mathrm{pH}$ & $7.2 \pm 0.07^{\mathrm{a}}$ & $6.7 \pm 1.20^{\mathrm{a}}$ & $6.7 \pm 0.28^{\mathrm{a}}$ & $6.5 \pm 0.71^{\mathrm{a}}$ \\
\hline $\mathrm{EC}(\mu \mathrm{S} / \mathrm{cm})$ & $123.6 \pm 8.52^{\mathrm{a}}$ & $390.5 \pm 187.59^{\mathrm{a}}$ & $356.2 \pm 8.04^{\mathrm{a}}$ & $958.8 \pm 569.73^{b}$ \\
\hline $\mathrm{NO}_{3}-\mathrm{N}(\mathrm{mg} / \mathrm{l})$ & $0.03 \pm 0.01^{\mathrm{a}}$ & $0.25 \pm 0.16^{\mathrm{b}}$ & $0.07 \pm 0.16^{\mathrm{a}}$ & $0.08 \pm 0.07^{\mathrm{a}}$ \\
\hline $\mathrm{NH}_{4}-\mathrm{N}(\mathrm{mg} / \mathrm{l})$ & $0.02 \pm 0.03^{\mathrm{a}}$ & $2.25 \pm 1.65^{\mathrm{a}}$ & $0.08 \pm 0.10^{\mathrm{a}}$ & $14.98 \pm 16.62^{\mathrm{b}}$ \\
\hline $\mathrm{PO}_{4}-\mathrm{P}(\mathrm{mg} / \mathrm{l})$ & $0.08 \pm 0.04^{\mathrm{a}}$ & $1.88 \pm 2.11^{\mathrm{a}}$ & $0.06 \pm 0.06^{\mathrm{a}}$ & $4.72 \pm 5.20^{\mathrm{b}}$ \\
\hline $\mathrm{K}^{+}(\mathrm{mg} / \mathrm{l})$ & $6.14 \pm 2.06^{\mathrm{a}}$ & $35.79 \pm 18.18^{b}$ & $6.14 \pm 1.78^{\mathrm{a}}$ & $35.57 \pm 36.15^{\mathrm{b}}$ \\
\hline $\mathrm{Ca}^{2+}(\mathrm{mg} / \mathrm{l})$ & $7.33 \pm 0.99^{\mathrm{a}}$ & $37.86 \pm 24.82^{\mathrm{bc}}$ & $15.67 \pm 1.40^{\mathrm{ab}}$ & $49.30 \pm 31.18^{c}$ \\
\hline $\mathrm{Na}^{+}(\mathrm{mg} / \mathrm{l})$ & $13.42 \pm 0.54^{\mathrm{a}}$ & $25.96 \pm 9.47^{\mathrm{ab}}$ & $25.40 \pm 5.90^{\mathrm{ab}}$ & $38.83 \pm 19.81^{\mathrm{b}}$ \\
\hline $\mathrm{Mg}^{2+}(\mathrm{mg} / \mathrm{l})$ & $2.65 \pm 0.23^{\mathrm{a}}$ & $11.44 \pm 7.42^{\mathrm{ab}}$ & $4.46 \pm 1.03^{\mathrm{a}}$ & $15.18 \pm 13.07^{\mathrm{b}}$ \\
\hline
\end{tabular}

Water Samples were collected in non-flooded condition on April 30 and in flooded condition on June 20, 2012 at GS. Letters on the table indicate significant difference at the $5 \%$ level based on Duncan's test.

and $\mathrm{PO}_{4}-\mathrm{P}$ contents at GS were abnormal. This may have resulted from stream-flow input from a surrounding rice field and a rubbish heap and mat decomposition under high temperature. Second, concentration of divalent cations at PC also deviated from typical value. PC area included a pasture near a road and received a great amount of snowfall every winter. $\mathrm{CaCl}_{2}$ salt could have caused the high $\mathrm{Ca}^{2+}$ content in water at PC.

Soil was a little acidic and similar at four habitats except at DG. C. virosa primarily lives on grey-wooded and podzolic soils with peat in northern Canada (Mulligan and Munro 1980). Our results support these observations, but an evaluation of the effect of the excessive $\mathrm{Na}^{+}$concentration in soil and the high $\mathrm{Ca}^{2+}$ content in water at PC to C. virosa distribution is needed additionally.

In mat system of GS, almost all ion concentrations in the interstitial mat water were higher than those in the free surface water in July than those in April. But, $\mathrm{NO}_{3}-\mathrm{N}$ content was higher in April under the non-flooded condition than that in July, because the redox potential decreased under the flooded condition (Haraguchi 1991). Water chemistry and redox potential of a floating mat is affected by water regime (Haraguchi 2004).

Synthetically, total distribution ranges of water and soil chemical environment for C. virosa were wide and overlapped with the optimal environmental range of distribution for typical hydrophytes such as Z. latifolia, Typha augustifolia (Kwonet al. 2006), Scirpus tabernaemontani (Lee et al. 2007), and Juncus effuses (Yoon et al. 2011). Water and soil chemical properties at C. virosa population were not different from those at major companion species mono-populations at each site.

\section{Water level as a factor determining $C$. virosa distribution}

The distribution of adult wetland plants can be determined by a single environmental gradient such as water depth (Spence 1982, Coops et al. 2004, Lee et al. 2005), because changes in water depth are associated with changes in a variety of environmental factors (e.g., light, soil nutrients, soil particle size, gas exchange rates) that physiologically constrain species distribution (Spence 1982, Keddy 1983). In addition, each species can be expected to have its own water depth tolerance (Spence 1967, Seabloom et al. 1998) and plant communities are more likely to respond to the history of water level than the water level at a particular time of a survey (Roberts 1994, Tabacchi 1995). This means that water level and competitive interactions with accompanying species under seasonal changes in water depth are important factors for the distribution and population size of hydrophytes.

We determined that there were meaningful differences between water levels of $C$. virosa populations and major accompanying species mono-populations (P. thunbergii at HS1, P. japonica at HS2, Z. latifolia at GS) (Fig. 5b). A mound shaped surface that was modified by $P$. japonica may change its micro-environment and affect reproductive success of other species (Byun et al. 2008, Hong et al. 2012). The P. japonica hummock offered a low water level for C. virosa at HS2, which consisted of a $30 \mathrm{~cm}$ deep streamlet. Floating mats rise and fall with changes in local water level and support stands of emergent vascular vegetation (Sasser et al. 1991). Mat made of live and dead roots and non-decomposing parts of plants like $P$. distichum and $Z$. latifolia provided shallow water level at GS, a $1 \mathrm{~m}$ depth reservoir and shelter from strong competition with a prolific accompanying species, $Z$. latifolia and 
disturbance by flooding in summer. Water depth for the distribution of adult $C$. virosa was defined as $7 \pm 3.5 \mathrm{~cm}$, which was the mean water depth value at three habitats (HS1, HS2, and GS) through the entire growing season. A study reported that $C$. virosa lives on sand in $0-20 \mathrm{~cm}$ water levels with light over 12,000 lux on Mt. Baekdu in China (Kim and Lee 2003).

The abundance of $C$. virosa within its native range has been diminished where water courses and marshes have been diverted, filled, or drained (Mulligan and Munro 1980, this study). Vegetation studies have often revealed significant declines in area and/or species richness of shore vegetation after water regime alterations (Nilsson and Keddy 1988, Shay et al. 1999, Nishihiro et al. 2004, this study). In Japan, the major reason for the extinction of wild plants and decreases in their number is exploitation of wetlands (Jeon 1999). The population size of C. virosa was diminished at PC and DG where the water regime was changed due to fragmentation by road construction and isolation by a protection fence. There was a water shortage in May and June at PC and a need for an artificial water supply from the near mountain at DG. Monthly water levels from substrate C.virosa rooted in changed and were significantly different at the four sites because of different water regime. But, water levels in May were not different among habitats where $C$. virosa population sizes were large, and average water level was $7.2 \pm 2.4 \mathrm{~cm}$ (Fig. 5a). The spring season is a very important period for regeneration and distribution of C. virosa considering its life history (Fig. 4). C. virosa sprouted earlier than other plants and flowered in July at PC.

Dispersal strategy of water hemlock is floating and spreading through water flooding in spring (Mulligan and Munro 1980, Panter et al. 1988); hence, sufficient water level could be a factor determining C. virosa distribution. Water hemlock forms overwintering rootstocks from buds around the base of the current year's rootstock in the fall. These may keep the plant afloat and serve to spread plants during spring flooding. The seeds, which are surrounded by a spongy fruit coat, are also buoyant (Mulligan and Munro 1980).

As a result, proper water level is a very important factor determining C. virosa distribution and dispersal, and the low water level in spring was considered a reason that the C. virosa population has decreased at PC and DG. We could propose connecting with corridor that $C$. virosa could use to disperse through and maintaining a high water level to preserve and restore C. virosa habitats. Here, the GS habitat could be a good model for $C$. virosa conservation in a warm temperate region.

\section{CONCLUSION}

C. virosa habitats were distinguished by comparison based on climate, wetland type, community structure, water and substrate properties and water regime. HS1 had a $0-5 \mathrm{~cm}$ water depth abandoned rice field in high montane areas with emerging $P$. thunbergii, and its ion concentrations and EC were in the midrange and relatively constant. HS2 had a 10-15 cm water depth streamlet in high montane areas with P. japonica and its ion concentrations and EC were relatively poor and constant. GS was $0-10 \mathrm{~cm}$ water depth (to mat surface) a deep reservoir where floating mat developed at low altitudes and in a warm area. The main companion species was Z. latifolia and its ion concentrations and EC were relatively rich and seasonally highly variable. PC was dominated by S. radicans and has excessive high EC value in water and high $\mathrm{Na}^{+}$contents in soil with the low water level in spring in high montane area.

The total distribution ranges of the water and soil chemical environments for $C$. virosa were wide and overlapped with the optimal environmental range of distribution for accompanying species. However, the optimal water level range for $C$. virosa distribution and dispersal could be defined. This optimum water level was adjusted by substrate structure such as a mound of P. japonica and a floating mat comprised of accompanying species. A floating mat at GS was an aid to maintain an optimal and stable water level in deep or fluctuating water and to prevent strong competition with prolific macrophytes. The GS, which had floating mats, could be a good model for $C$. viros a conservation in a warm temperate region, whereas the PC, which experienced a water shortage in spring, provided a clue about the decline in C. virosa population size.

\section{ACKNOWLEDGMENTS}

This study was supported by Korea Ministry of Environment as "The Eco-Innovation project 416-111-010". I should like to thank Mr. Y.C. Kim, for offering basic information of $C$. virosa habitats willingly.

\section{LITERATURE CITED}

Allen SE, Grimshaw HM, Parkinson JA, Quarmby C. 1974. Chemical Analysis of ecological materials. Blackwell Scientific Publications, Oxford. 
Boyle J. 2004. A comparison of two methods for estimating the organic matter content of sediments. J Paleolimnol 31: 125-127.

Bray RH, Kurtz LT. 1945. Determination of total, organic and available forms of phosphorous in soil. Soil Sci 59: 39-45.

Byun C, Kwon GJ, Lee D, Wojdak JM, Kim JG. 2008. Ecological assessment of plant succession and water quality in abandoned rice fields. J Ecol Field Biol 31: 213-223.

Canfield RH. 1941. Application of the line intercept method in sampling range vegetation. J Forest 39: 388-394.

Casanova MT, Brock MA. 2000. How do depth, duration and frequency of flooding influence the establishment of wetland plant communities? Plant Ecol 147: 237-250.

Coops H, Vulink JT, van Nes EH. 2004. Managed water levels and the expansion of emergent vegetation along a lakeshore. Limnologica 34: 57-64.

Fitter AH. 1982. Influence of Soil Heterogeneity on the Coexistence of Grassland Species. J Ecol 70: 139-148.

Haraguchi A. 1991. Effects of water-table oscillation on redox property of peat in a floating mat. J Ecol 79: 1113-1121.

Haraguchi A. 2004. Seasonal changes in redox properties of peat, nutrition and phenology of Menyanthes trifoliata L.in a floating peat mat in Mizorogaike Pond, central Japan. Aquat Ecol 38: 351-357.

Heegaard E, Birks HH, Gibson CE, S. Smith SJ, Wolfe-Murphy S. 2001. Species-environmental relationships of aquatic macrophytes in Northern Ireland. Aquat Bot 70: 175-223.

Hong MG, Nam JM, Kim JG. 2012. Occupational strategy of runner reed (Phragmites japonica): change of growth patterns with developmental aging. Aquat Bot 97: 30-34.

Jang SK, Cheon KS, Jeong JH, Kim ZS, Yoo KO. 2009. Environmental characteristics and vegetation of Megaleranthis saniculifolia Ohwi habitats. Korean J Environ Biol 27: 314-322 (in Korean).

Japanese Wildlife Research Association. 2012. Japanese local red lists http://www.jpnrdb.com/search. php?mode $=$ map \&q=06031083218 Accessed 7 Jun 2012 (in Japanese).

Jeon ES. 1999. Role of arboretum and botanical garden as conservation house of wild plants. Native Plants 48: 3438 (in Korean).

Kadlec RH, Knight RL. 1996. Treatment Wetlands. Lewis Publishers, Boca Raton, Florida, pp 102-105.

Kamphake LJ, Hannah SA, Cohen JM. 1967. Automated analysis for nitrate by hydrazine reduction. Water Res 1: 205-216

Keddy PA. 1983. Shoreline vegetation in Axe Lake, Ontario: effects of exposure on zonation patterns. Ecology 64: 331-344.
Keddy PA. 1984. Plant zonation on lakeshores in Nova Scotia: a test of the resource specialization hypothesis. J Ecol 72: 797-808.

Kim JG, Park JH, Choi BJ, Sim JH, Kwon GJ, Lee BA, Lee YW, Ju EJ. 2004. Method in Ecology. Bomoondang, Seoul (in Korean).

Kim SN, Lee JS. 2003. Ecological characteristics and growth environment of Korean native water plants. J Korean Flower Res Soc 11: 21-35 (in Korean).

Kingsbury JM. 1964. Poisonous plants of the United States and Canada. Prentice-hall, Inc., New Jersey.

Korean Environment Institute. 2005. A Study for General Planning of Wildlife Protection. Ministry of Environment (in Korean).

Kwon GJ, Lee BA, Byun C, Nam JM, Kim JG. 2006. The optimal environmental range for wetland plants: Zizania latifolia and Typha angustifolia. J Korean Environ Restor Technol 9: 72-88 (in Korean).

Lee CB. 2003. Coloured Flora of Korea. Hyangmoonsa, Seoul (in Korean).

Lee BA, Kwon GJ, Kim JG. 2005. The relationship of vegetation and environmental factors in Wangsuk stream and Gwarim reservoir: 1. water environments. J Ecol Field Biol 28: 365-373.

Lee BA, Kwon GJ, Kim JG. 2007. The optimal environmental ranges for wetland plants: 2. Scirpus tabernaemontani and Typha Latifolia. J Ecol Field Biol 30: 151-159.

Mueller-Dombois D, Ellenberg H. 2003. Aims and Methods of Vegetation of Ecology. Blackburn Press, New York.

Mulligan GA, Munro DB. 1981. The biology of Canadian weeds: 48. Cicuta malaculata L, C. douglasii .DC.. Coult. \& Rose and C. virosa L. Can J Plant Sci 61: 93-105.

Murphy J, Riley JP. 1962. A modified single solution method for the determination of phosphate in natural waters. Anal Chem Acta 27: 31-36.

National Arboretum. 2009. Korean Rare Plants List (in Korean).

National Weather Services. 2011. Monthly mean temperature and precipitation. http://www.kma.go.kr/weather/ observation/past_table.jsp. Accessed 18 Jul 2012 (in Korean).

Nilsson C, Grelsson G, Johansson M, Sperens U. 1989. Patterns of plant species richness along riverbanks. Ecology 70: 77-84.

Nilsson C, Keddy PA. 1988. Predictability of change in shoreline vegetation in a hydroelectric reservoir, Northern Sweden. Can J Fish Aquat Sci 45: 1896-1904.

Nishihiro J, Miyawaki S, Fujiwara N, Washitani I. 2004. Regeneration failure of lakeshore plants under an artificially altered water regime. Ecol Res 19: 613-623. 
Panter KE, Keeler RF, Baker DC. 1988. Toxicoses in livestock from the hemlocks (Conium and Cicuta spp.). J Anim Sci 66: $2407-2413$.

Sarreveld E. 1975. Cicutoxin poisoning (water hemlock). Neurology 25: 730.

Sasser CE, Gosselink JG, Shaffer GP. 1991. Distribution of nitrogen and phosphorus in a Louisiana freshwater floating marsh. Aquat Bot 41: 317-331.

Seabloom E, van der Valk A, Moloney K. 1998. The role of water depth and soil temperature in determining initial composition of prairie wetland coenoclines. Plant Ecol 138: 203-216

Suh MH, Koh KS, Ku YB, Choi TB, Suh SU, Oh HK, Hyun JO, Koh JG. 2001. Reserch on the Conservation Strategy for the Endangered and Reserved Plants Based on the Ecological and Genetic Characterestics (I). National Institute of Environmental Research (in Korean).

Shay J, de Geus P, Kapinga M. 1999. Changes in shoreline vegetation over a 50-year period in the Delta Marsh, Manitoba in response to water levels. Wetlands 19: 413425

Sheldrick BH, Wang C. 1993. Particle size distribution. In: Soil Sampling and Methods of Analysis (Carter MR, ed). Lewis, Florida, pp 499-511.

Solorzano L. 1969. Determination of ammonia in natural waters by the phenolhypochlorite method. Limnol Oceanogr 14: 799-801.
Song JM, Lee GY, Kim NY, Yi JS. 2010. Vegetation structure and site environment of natural habitat of an endangered plant, Viola websteri. J Korean For Soc 99: 267-276 (in Korean).

Spence DHN. 1967. Factors controlling the distribution of freshwater macrophytes with particular reference to the lochs of Scotland. J Ecol 55: 147-170.

Spence DHN. 1982. The zonation of plants in freshwater lakes. In: Advances in Ecological Research (Macfadyen A, Ford ED, eds). Academic Press, New York, pp 37-125.

Strauß U, Wittstock U, Schubert R, Teuscher E, Jung S, Mix E. 1996. Cicutoxin from Cicuta virosa- a new and potent potassium channel blocker in T Lymphocytes. Biochem Biophys Res Commun 219: 332-336.

Tabacchi E. 1995. Structural variability and invasions of pioneer plant communities in riparian habitats of the middle Adour River (SW France). Can J Bot 73: 33-44.

Tatár S. 2010. Seed longevity and germination characteristics of six fen plant species. Acta Biol Hung 61: 197-205.

You JH, Cho HW, Jung SG, Lee CH. 2004. Correlation analysis between growth and environmental characteristics in Abeliophyllum distichum habitats. Korean J Environ Ecol 18: 210-220 (in Korean).

Yoon J, Kim H, Nam JM, Kim JG. 2011. Optimal environmental range for Juncus effusus, an important plant species in an endangered insect species (Nannopya pygmaea) habitat in Korea. J Ecol Field Biol 34: 223-235. 